\title{
BVDV and BHV-1 Infections in Dairy Herds in Northern and Northeastern Thailand
}

\author{
By J. Kampa ${ }^{a, b, c}$, K. Ståhl ${ }^{a}$, J. Moreno-López ${ }^{a}$, A. Chanlun $^{c, d}$, S. Aiumlamai ${ }^{e}$ and S. Alenius ${ }^{c}$
}

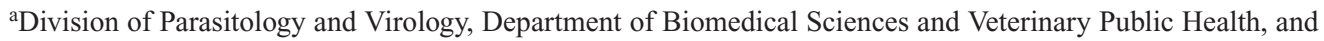
${ }^{c}$ Department of Ruminant Medicine and Veterinary Epidemiology, Faculty of Veterinary Medicine and Animal Science, Swedish University of Agricultural Sciences, Uppsala, Sweden, and bepartment of Pathobiology, ${ }^{\mathrm{d} D e-}$ partment of Medicine, and e Department of Surgery and Theriogenology, Faculty of Veterinary Medicine, Khon Kaen University, Thailand.

\begin{abstract}
Kampa J, Ståhl K, Moreno-López J, Chanlun A, Aiumlamai S, Alenius S: BVDV and BHV.1 infections in dairy herds in northern and northeastern Thailand. Acta vet. scand. 2004, 45, 181-192. - Bulk milk samples from 220 dairy herds were collected at 9 public milk collection centres in the northeastern and northern Thailand, and a subset of 11 herds was selected for individual testing. The samples were tested for presence of antibodies to BVDV and BHV-1 using an indirect ELISA. The results from the bulk milk testing demonstrated a moderate level of exposure to BVDV and BHV-1 (73\% and $67 \%$, respectively). However, the low proportion of herds with high BVDV antibodylevels $(13 \%)$ and the low within-herd seroprevalence of BVDV and BHV-1 in the 11 herds $(24 \%$ and $5 \%$, respectively), particularly among the young stock $(15 \%$ and $0 \%$, respectively), demonstrated a low prevalence of active BVDV infection and a low rate of reactivation of latent BHV-1. The presence of a self-clearance process was also indicated by the results from the individual testing. Moreover, a surprisingly low prevalence of BVDV and BHV-1 antibody-positive herds at one of the milk centres was found. This centre was established 5-10 years before the others. Our impression is that this reflects the self-clearance process, where consecutive replacement of imported infected animals without further spread has resulted in a nearly total elimination of the infections.

Based on our experiences and on these results we are convinced that this process can continue if there is awareness of herd biosecurity. This is especially important in the context of a future intensification of the dairy production.
\end{abstract}

BVDV; BHV-1; bulk milk; prevalence; Thailand.

\section{Introduction}

Bovine viral diarrhoea virus (BVDV) and bovine herpesvirus type 1 (BHV-1) are wellknown, important pathogens of cattle that give rise to substantial economic losses due to reproductive failures and increased calf mortality, as well as enteric and respiratory disease. These pathogens have a worldwide distribution and tend to be endemic in most populations, although national and regional variations occur (for BVDV review see Nettleton \& Entrican 1995, Houe 1999, Lindberg 2003; for BHV-1 review see Gibbs \& Rweywmamu 1977, Kahrs 2001, Straub 2001).

Vaccination has been the conventional way to control or reduce losses caused by BVDV and BHV-1 for the last 4-5 decades (Brock 2004, Kahrs 2001). The number of licensed vaccines on the market is vast and they are widely used. The use of vaccines may reduce economic losses caused by clinical disease, but does not appear to result in reduction of the prevalence of either BVDV or BHV-1 infections (van 
Oirschot et al. 1996, O'Rourke 2002). The introduction of gene-deleted vaccines was considered a breakthrough for the control of BHV-1 (Straub 2001). During 1998-1999 a live attenuated $\mathrm{gE}$-deleted marker vaccine provided the basis for a compulsory control programme in the Netherlands. However, a severe outbreak of BVDV type 2 on several dairy farms, induced by contaminated gE-deleted marker vaccine, was a drawback that illustrated the potential risks with the use of live vaccines (Barkema et al. 2001). During the last decades eradication programmes against BVDV and BHV-1, without the use of vaccines, have been implemented in some European countries. These have been based on identification and elimination of carrier animals, together with increased herd biosecurity. The national BVD programmes in the Scandinavian countries, as well as the regional programmes in a few other countries in Europe, have had success with control of BVDV and are aiming towards eradication (Waage et al. 1994, Lindberg \& Alenius 1999, Nuotio et al. 1999, Synge et al. 1999, Bitsch et al. 2000). Eradication of BHV-1, i.e. official declaration of freedom by the EU or Efta, has already been achieved in Switzerland, Norway, Finland, Denmark, Sweden, Austria and the province of Bolzano in Italy (Ackermann et al. 1990, SCAHAW 2000).

Experiences from the Swedish BVDV programme have shown that self-clearance, i.e. the process whereby an infection is eliminated from a population without intervention, is an important phenomenon that works in favour of any BVDV control scheme. Self-clearance occurs when persistently infected (PI) animals are removed from the herd (due to death, trade or culling) before they succeed in establishing additional persistent infections, and seems to be more frequent in smaller herds. However, harder rearing conditions, as might be seen in larger herds with intensive production, may in- crease the risk for early death in PI animals and may consequently increase the probability for self-clearance (Lindberg \& Alenius 1999). Selfclearance has, to our knowledge, not been described for BHV-1 infections. During the Swedish BHV-1 programme, however, reports on herds changing BHV-1 status from positive to negative without intervention between consecutive samplings, indicated a self-clearing process. Replacement of animals latently infected with BHV-1 before any reactivation of latent virus will result in self-clearance as long as introduced or newborn animals are BHV-1 negative.

Information on the epidemiology and impact of BVDV and BHV-1 in developing countries is limited, even though serological surveys have been performed in several countries in Asia, Africa and Latin America (Rweyemamu et al. 1990, Baule et al. 1997, Virakul et al. 1997, Obando et al. 1999, Ståhl et al. 2002). Given the assumption that presence of antibodies reflects exposure to a pathogen, these surveys show that BVDV and BHV-1 are widespread. However, considering the persistence of BVDV and BHV-1 specific antibodies and the phenomenon of self-clearance (Kaashoek et al. 1996, Fredriksen et al. 1999, Lindberg \& Alenius 1999), serosurveys may give positive results years after last exposure to virus.

Dairy production in Thailand dates back to the 1960s when dairy cattle were imported to the central provinces of the country. The number of establishments increased rapidly during the following decades to meet the increasing demand. Since the early 1990s, smallholder dairy farming has been encouraged in other parts of the country, including the northeastern and northern provinces. Dairy cattle have been introduced to the new establishments mainly from the central provinces, but also through imports from other countries.

The purpose of this study was to estimate the 


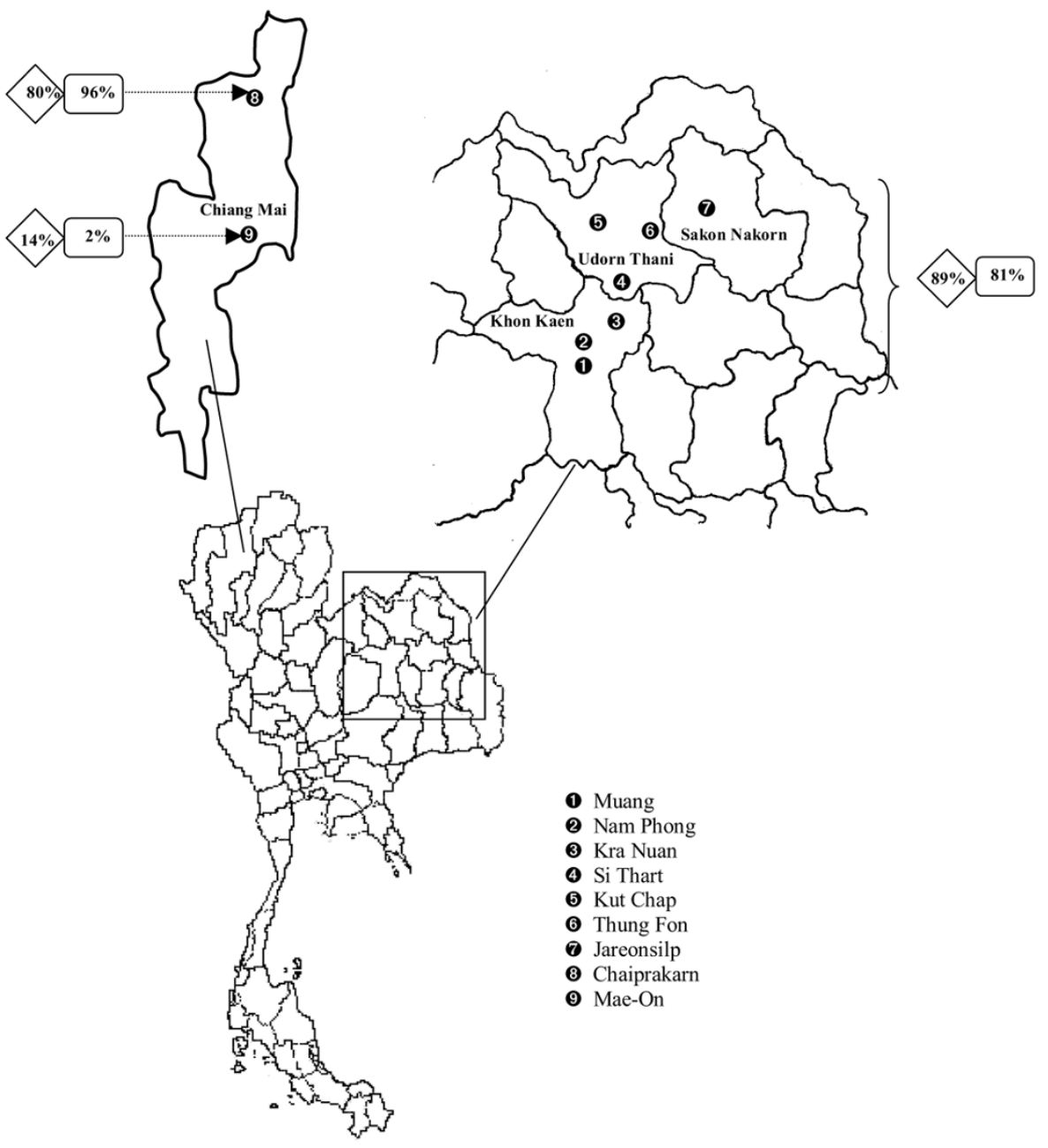

Figure 1. Map of Thailand showing the location of the 9 public milk centres from which the bulk milk samples were collected. The prevalence of BVDV ad BHV-1 seropositive herds among the 220 herds in milk centres 1-7, milk centre 8 and milk centre 9 , are shown within diamonds and squares, respectively.

prevalence of BVDV and BHV-1 in dairy cattle in the northeastern and northern parts of Thailand and to study the epidemiological patterns of the viruses. The purpose was also to estimate the prevalence of active or recent infection of BVDV and BHV-1, with the aim to make recommendations for disease control.

\section{Materials and methods}

Study population and survey design

This survey was carried out in 4 provinces in Thailand, 3 in northeast: Khon Kaen, Udorn Thani and Sakon Nakorn and one in north: Chiang Mai (see map, fig. 1). The average size of a dairy herd in the region is $10-20$ milking cows, 
with mixed Holstein-Friesian and Sahival breeds, and with a daily milk production of approximately $9-11 \mathrm{~kg} / \mathrm{cow}$ (Department of Livestock Development 2002). Most of the production in these provinces is commercialised through public milk collection centres. ${ }^{1}$

Two hundred and twenty dairy herds were randomly selected from 9 milk centres: 7 located in the northeastern provinces (milk centres 1-7) and 2 in one of the northern provinces (milk centres 8-9). These herds represented approximately $20 \%$ of the dairy herds in the 9 milk centres (range: 10\%-36\%). From this set of herds, a subset of 11 herds located in the Khon Kaen province (milk centres 1 and 2) was also selected. This selection was based on accessibility. Vaccination against BVDV or BHV-1 had not been practised in this part of the country.

\section{Collection of samples}

Bulk milk samples from all 220 herds were collected at the public milk collection centres: during May to August 2000 in the northeastern provinces (151 herds) and during January to June 2001 in the northern (69 herds). A second sampling was carried out in August 2001 on the 11 selected farms, where individual serum samples from all animals were collected. All samples were transported at $4-8^{\circ} \mathrm{C}$ to the laboratory on the day of the sampling and centrifuged at $1000 \mathrm{x}$ g. The samples were then inactivated at $56^{\circ} \mathrm{C}$ for $30 \mathrm{~min}$ and stored at $-20^{\circ} \mathrm{C}$ in $2.0 \mathrm{ml}$ vials until analysed at the Faculty of Veterinary Medicine and Animal Science, Swedish University of Agricultural Sciences, Uppsala, Sweden.

\footnotetext{
1 "Milk centre", when used further on in the text, refers to the population of herds delivering milk for commercialisation to a specific public milk collection centre.
}

\section{Serological testing and interpretation}

Commercial indirect ELISA kits with antigencoated microtitre plates were used for detection of antibodies to BVDV and BHV-1 in bulk milk and in serum, according to the instructions of the manufacturer (SVANOVA Biotech AB, Uppsala, Sweden). The corrected optical density (COD) level was calculated before interpretation of the results by subtracting the optical density (OD) for the control antigen from sample OD (OD $\left.{ }^{\text {sample }}-\mathrm{OD}^{\text {control }}=\mathrm{COD}\right)$.

The Swedish system of classification and interpretation of the results of the BVDV antibody ELISA on bulk milk was used whereby herds are allocated into 4 different classes based on COD levels. Herds in classes 0 or 1 (CODs $<0.05$ or between $0.05-0.24$, respectively) have a very low or low level of antibodies in the bulk milk and are unlikely to contain persistently infected animals, unless these have been recently introduced. Herds in classes 2 or 3 (CODs between $0.25-0.54$ or $\geq 0.55$ respectively) have a moderate or high level of antibodies. Herds with active BVDV infection, i.e. herds with PI animals are most likely to be found among class 3 herds, since the presence of a PI animal in a herd generally expresses itself as a high degree of seroconversion in the surrounding animals, resulting in high levels of antibodies in the bulk milk and, consequently, high CODs. These herds will also, in general, have a high seroprevalence among the young stock (Lindberg \& Alenius 1999).

The results of the BHV-1 antibody ELISA on bulk milk were interpreted according to the Swedish IBR control programme, i.e. samples with CODs $\geq 0.05$ were considered positive.

Sera from animals older than 6 months, in total 351 animals, were analysed for presence of antibodies to BVDV and BHV-1. The results were interpreted according to Juntti et al. (1987), i.e. sera with CODs $\geq 0.20$ were considered positive. BHV-1 antibody-positive individuals are 


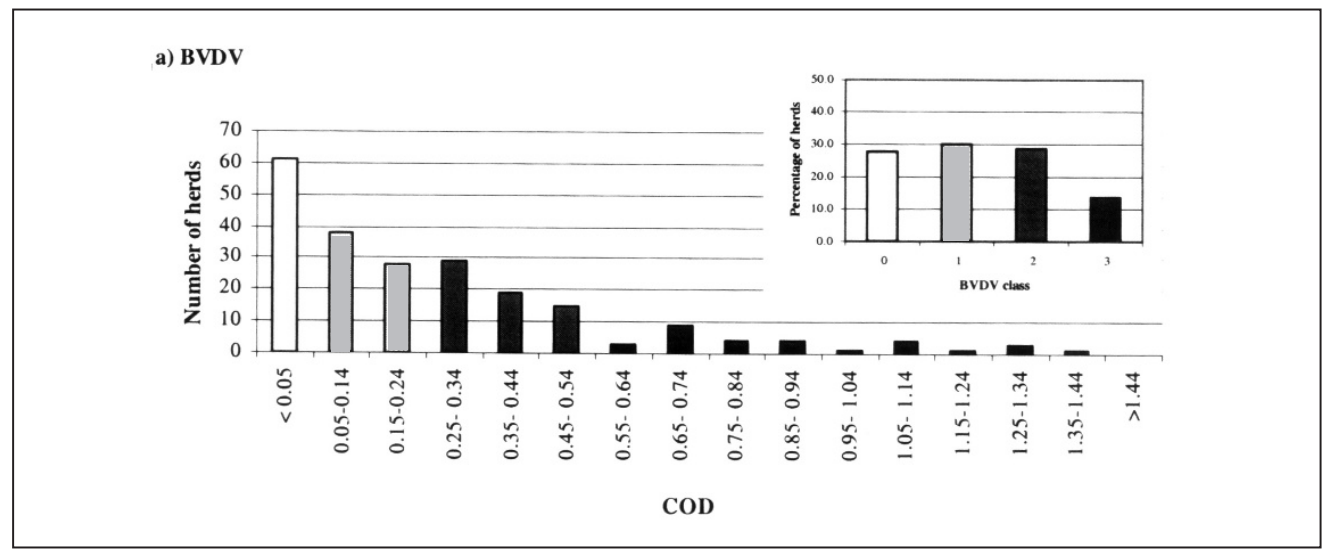

b) BHV-1

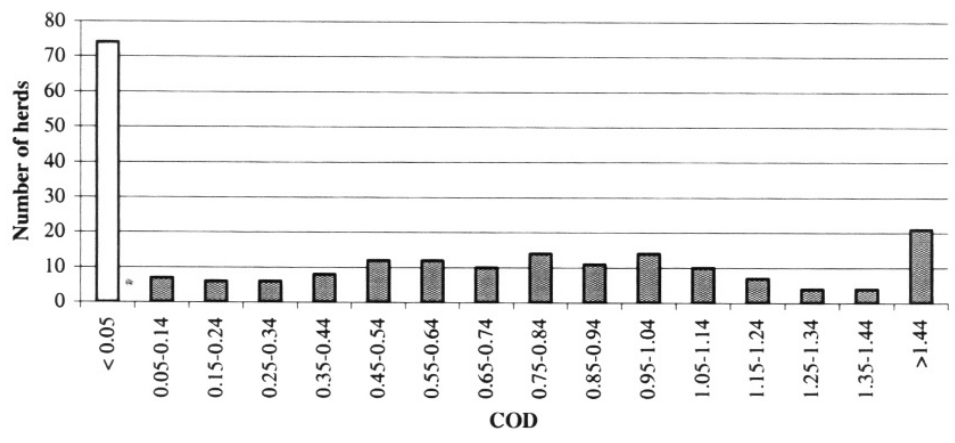

Figure 2. Frequency distribution of bulk milk corrected optical density (COD) values from the BVDV antibody assay (a) with an inserted histogram showing the percentage of herds in each BVDV class derived from the CODs, for 220 dairy herds in Thailand. (b) The frequency distribution of bulk milk COD from the BHV-1 antibody assay.

generally considered to be latently infected and to constitute a potential source of viral transmission (Ackermann et al. 1982). BVDV antibody-positive individuals, on the other hand, have in general recovered from infection and developed a lifelong immunity (Fredriksen et al. 1999). Animals persistently infected with BVDV are in general antibody-negative (Coria et al. 1972).

A commercial antigen ELISA (Herd Check BVDV Ag/Serum, Idexx laboratories, INC.) was used for detection of BVDV antigen in herds where the presence of PI animals could be suspected based on the results from the antibody ELISA testing. All seronegative animals older than 6 months and all animals younger than 6 months were tested in these herds. The analysis was performed according to the instructions of the manufacturer. The corrected optical density (COD) level was calculated before interpretation of the results by subtracting the mean OD for negative controls from sample 
Table 1. Results from BVDV and BHV-1 antibody analysis by indirect ELISA on 220 bulk milk samples collected at 9 public milk centres in northeastern (1-7) and northern (8-9) Thailand, 2000-2001.

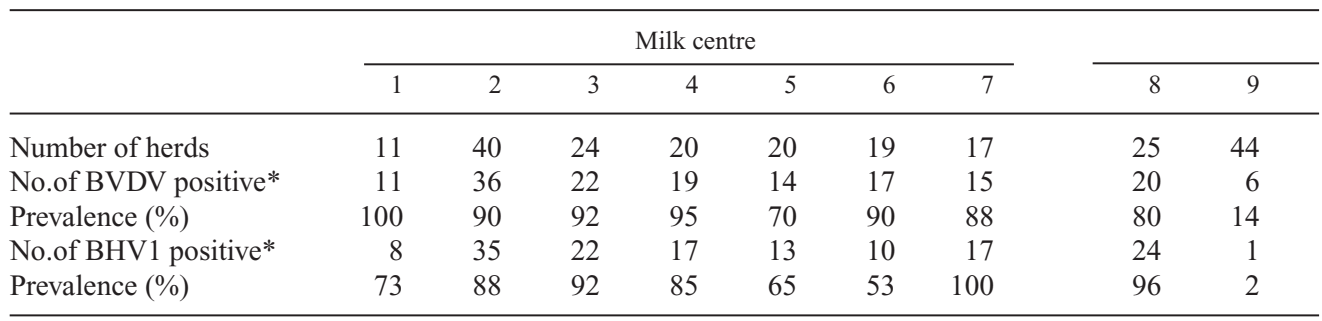

* Herds with CODs $\geq 0.05$ were considered antibody positive according to the Swedish BVDV and BHV-1 control programmes.

OD (OD ${ }^{\text {sample }}$ - meanOD $\left.{ }^{\text {negative }}=\mathrm{COD}\right)$. COD values $\leq 0.300$ were classified as being negative.

\section{Statistical analysis}

The Pearson Chi-square test was used to investigate a possible association between BVDV antibody status and BHV-1 status at the herd level and to analyse differences in prevalences of BVDV and BHV-1 antibody-positive herds between regions and between milk centres within the regions. The differences in mean bulk milk COD levels between the regions and between milk centres within the regions were analysed using the Wilcoxon rank sum-test

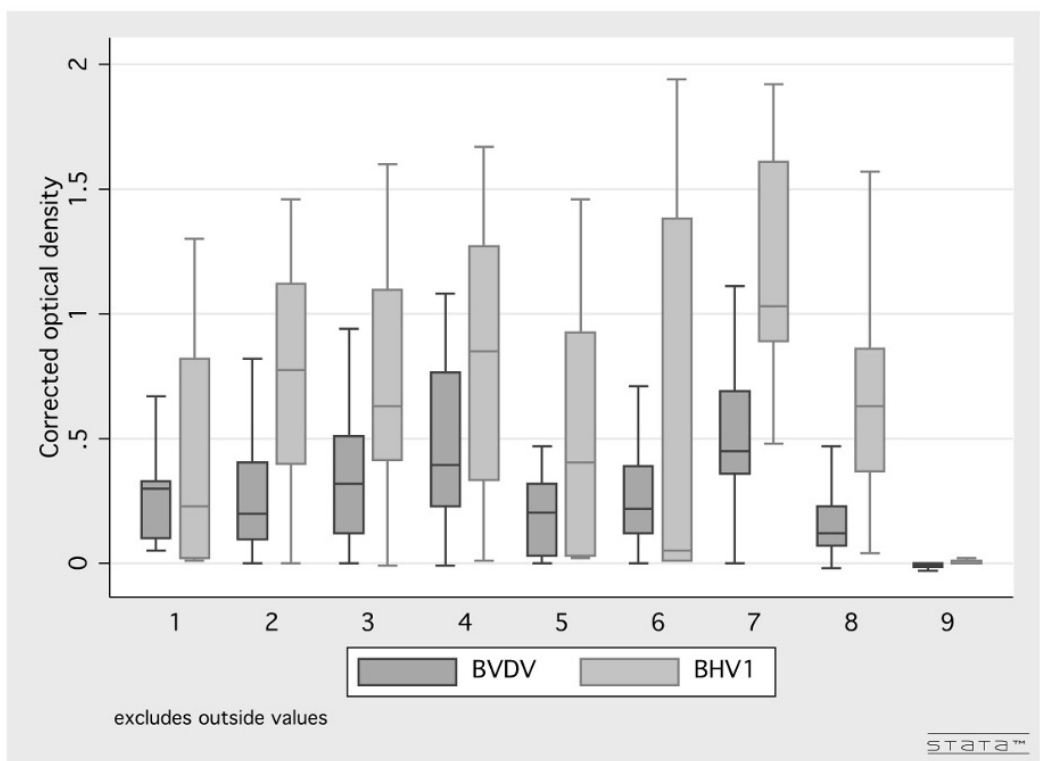

Figure 3. Box plot showing the distribution of bulk milk corrected optical densitiy (COD) values for BVDV and BHV-1 from dairy herds in nine public milk centres in Thailand, 2000-2001. Boxes represent the first quartile $\left(\mathrm{q}_{1}\right)$, median and third quartile $\left(\mathrm{q}_{3}\right)$ of the COD values from each milk centre, and lower $(\mathrm{L})$ and upper $(\mathrm{U})$ limits are defined as : $\mathrm{L}=\mathrm{q}_{1}-1.5 \mathrm{x} I \mathrm{IQR}$ and $\mathrm{U}=\mathrm{q}_{3}+1.5 \times \mathrm{IQR}$, where $\mathrm{IQR}=\mathrm{q}_{3}-\mathrm{q}_{1}$. 
Table 2. Results from BVDV and BHV-1 antibody analysis by indirect ELISA on sera from all animals older than 6 months in 11 dairy herds in the Khon Kaen province, Thailand, 2000-2001.

\begin{tabular}{|c|c|c|c|c|c|c|c|c|c|c|c|c|}
\hline & \multicolumn{11}{|c|}{ Herd } & \multirow[t]{2}{*}{ Total } \\
\hline & 1 & 2 & 3 & 4 & 5 & 6 & 7 & 8 & 9 & 10 & 11 & \\
\hline Number of animals & 34 & 19 & 37 & 31 & 23 & 26 & 29 & 40 & 41 & 38 & 33 & 351 \\
\hline No. of BVDV positive* & 4 & 2 & 5 & 4 & 3 & 8 & 2 & 22 & 11 & 20 & 2 & 83 \\
\hline Prevalence $(\%)$ & 12 & 11 & 14 & 13 & 13 & 31 & 7 & 55 & 27 & 53 & 6 & $24 * *$ \\
\hline No. of BHV-1 positive* & 2 & 2 & 5 & 3 & 3 & 1 & 0 & 2 & 0 & 0 & 0 & 18 \\
\hline Prevalence $(\%)$ & 6 & 11 & 14 & 10 & 13 & 4 & 0 & 5 & 0 & 0 & 0 & $5^{* *}$ \\
\hline
\end{tabular}

* Sera with CODs $\geq 0.20$ were interpreted as seropositive ** i.e. mean prevalence within the eleven herds

(Mann-Whitney). On the individual level, the data was stratified into 4 categories based on age, and individual BVDV and BHV-1 seroprevalences within each age category were calculated. The Pearson Chi-square test was used for the analysis. P-values $\leq 0.05$ were considered statistically significant. The statistical software, Stata, release 7.0 and 8.0 (StataCorp 2001, College Station, TX, USA) was used for all statistical analyses.

\section{Results}

\section{Bulk milk testing}

The distributions of bulk milk COD levels from BVDV and BHV-1 antibody assays are shown in fig. 2. The prevalence of BVDV antibodypositive herds (classes 1, 2 and 3) was $73 \%$ $(160 / 220)$ and that of BHV-1 67\% (147/220). Sixty-two per cent (136/220) of the herds had detectable levels of antibodies to both viruses in the bulk milk. Twenty-nine herds (13\%) had BVDV COD levels above 0.55 and were classified as class 3 herds. There was a highly significant relationship between a herd's BVDV antibody status and its BHV- 1 status $\left(\chi^{2}=87.5\right.$, $\mathrm{p}=0.000$ ).

The mean prevalences of BVDV and BHV-1 antibody-positive herds were significantly higher in milk centres 1-7 in the northeastern provinces (mean prevalences: $89 \%$ and $81 \%$, respectively) than in milk centres $8-9$ in the northern province (mean prevalences: $34 \%$ and $36 \%$, respectively; table 1). Milk centre 9 differed from all the other milk centres, with a very low prevalence of BVDV and BHV-1 antibody-positive herds (fig. 1), and significantly lower mean CODs (fig. 3). Antibodies to BVDV were detected in bulk milk from 6 out of 44 herds (14\%) at milk centre 9 , and antibodies to BHV-1 only in bulk milk from one herd $(2 \%)$.

\section{Individual testing}

The results from the individual testing of animals older than 6 months in the 11 herds are given in table 2. The within-herd seroprevalence of BVDV was low to moderate in all herds (mean 24\%; range: 6\%-55\%). The within-herd seroprevalence of BHV-1 was low in all herds (range: $70 \%-14 \%$ ) and in total, only 18 seropositive animals were found. Fifteen out of these were also seropositive to BVDV.

All eleven herds were BVDV positive based on bulk milk testing (mean COD: 0.13; range: 0.05-0.23) and 6 out of 11 were BHV-1 positive (mean COD: 0.20; range: 0-0.56). The 5 herds that were BHV-1 negative based on bulk milk testing were also free from seropositive individuals among the lactating cows (data not shown). In herd 8, however, 2 seropositive cows were detected among the non-lactating cows.

The distribution of seropositive animals by age 
Table 3. Distribution by age of BVDV and BHV-1 seropositive individuals among animals older than 6 months, in 11 dairy herds in the Khon Kaen province, Thailand, 2001.

\begin{tabular}{|c|c|c|c|c|c|}
\hline \multirow{2}{*}{$\begin{array}{l}\text { Age } \\
\text { (years) }\end{array}$} & \multirow{2}{*}{$\begin{array}{c}\text { No. of } \\
\text { animals }\end{array}$} & \multicolumn{2}{|c|}{ BVDV* } & \multicolumn{2}{|c|}{ BHV-1* } \\
\hline & & No.of positive & Prevalence (\%) & No.of positive & Prevalence (\%) \\
\hline$>6$ & 70 & 35 & 50 & 15 & 21 \\
\hline $4-6$ & 57 & 11 & 19 & 3 & 5 \\
\hline $2-4$ & 110 & 22 & 20 & 0 & 0 \\
\hline $0.5-2$ & 114 & 15 & 13 & 0 & 0 \\
\hline Total & 351 & 83 & 24 & 18 & 5 \\
\hline
\end{tabular}

* Sera with CODs $\geq 0.20$ were interpreted as seropositive.

is given in table 3. We found significantly higher seroprevalence of BVDV and BHV-1 among cows older than 6 years $(50 \%$ and $21 \%$ respectively) compared with that among animals younger than 6 years $(17 \%$ and $1 \%$ respectively; table 3 ). The mean age for the BHV1 seropositive animals was 8.2 years and none of the 224 animals between 6 months and 4 years had seroconverted to BHV-1. Only 15 of the 114 animals below 2 years had seroconverted to BVDV and the seroprevalence in this group was very low in 9 herds (herds 1-7, 9 and 11) and moderate to high in herds 8 and 10 (21\% and 64\% respectively; data not shown). No BVDV antigen-positive animals were detected.

\section{Discussion}

The results demonstrate a moderate level of exposure to BVDV and BHV-1 in the studied dairy population with prevalences of antibodypositive herds of $73 \%$ and $67 \%$, respectively. These prevalences are similar to those reported previously from northeastern Thailand (Virakul et al. 1997), and do not differ greatly from other parts of the world (Niskanen et al. 1991, Houe 1995, Paton et al. 1998, Straub 2001).

The proportion of BVDV class 3 herds was $13 \%$, indicating a low prevalence of active BVDV infection in the studied population. Results from previous publications demonstrate that the proportion of herds potentially having active BVDV infection shows a wide range of variation between countries and between regions within countries (Bitsch \& Rønsholt 1995, Paton et al. 1998, Nuotio et al. 1999, Graham et al. 2001, Mainar-Jaime et al. 2001, Ståhl et al. 2002, Viltrop et al. 2002). This variation may in part be explained by differences in demography, such as herd size and population density, and management factors such as the pattern and frequency of animal movements (Houe 1995).

There was a significant association between being antibody-positive to BVDV and being BHV-1-positive at the herd level. This corresponds with the results reported by Paton et al. (1998), suggesting that similar factors affect the risk of being infected with either virus. One major risk factor is the introduction of purchased animals with insufficient health documentation (Valle et al. 1999). In this context, we found the results from milk centre 9 interesting. The prevalence of BVDV and BHV-1 antibodypositive herds at milk centre 9 was very low ( $14 \%$ and $2 \%$, respectively) compared with the other milk centres and in sharp contrast with the neighbouring herds at milk centre 8 . It was beyond the scope of this study to explain this finding as demography, and management practices were not studied in detail. However, we know that most of the herds at milk centre 9 
were established in the late $1980 \mathrm{~s}$, whereas most of the herds at milk centres 1 to 8 were established around 1995. One might thus speculate that one reason for the aberrant finding is the difference in time that has passed since the milk centres were established; that the higher prevalence in the herds at milk centres 1 to 8 to a large extent represents historical infections (for BVDV) or latent infections (for BHV-1) in introduced, i.e. imported, cattle. At milk centre 9 , on the other hand, the process has gone further and replacement of infected, imported animals most probably has occurred over the years, resulting in a nearly total self-clearance of both BVDV and BHV-1. This hypothesis, however, needs to be further investigated.

The selection of the 11 herds used for the individual testing was not based on a random procedure and represents only 2 of the milk centres. Therefore, these results cannot be generalised to the entire population. Nevertheless, they do provide new knowledge on the regional BVDV and BHV-1 situation. The age distribution of BVDV seropositive animals in 9 of the herds clearly demonstrates 2 things: firstly, absence of PI animals and secondly that the herds have been exposed to BVDV in the past. According to our experiences from the Swedish BVD programme this indicates that self-clearance has occurred. The corresponding results from herd 8 and especially herd 10, on the other hand indicated, possible presence of PI animals. To investigate these findings and to identify PI animals, sera from all seronegative cows and all calves (including calves younger than 6 months) in herds 8 and 10 were analysed by antigen ELISA, with negative results. It is possible that PI animals have been present in the herds recently but that they have died or been traded before our sampling. But if they succeeded to transmit the virus to susceptible dams in early pregnancy, new PI's will be born, and the infection will be maintained within the herd. Therefore, these 2 herds should be kept under surveillance.

The results of the individual testing also suggest an absence of active BHV-1 infection in the 11 herds, with the lack of seroreactors among cows younger than 4 years. Moreover, we found evidence that at least 14 out of 18 seropositive cows had in fact been imported, indicating that no or very limited virus transmission had occurred following their introduction. This corresponds with the results reported by Pritchard (1992), suggesting that the risk for reactivation of latent BHV-1 infections under natural conditions has been overestimated in the past and that self-clearance may occur. This is probably particularly true in regions with low-intensive production systems, i.e. with low levels of stress to the animals.

Finally, the results suggest a low rate of reactivation of latent BHV-1 infections and indicate a progressive self-clearance of BVDV as well as BHV-1. Based on our experiences from Sweden and on these results we are convinced that this process can continue as long as introductions of infection to non-infected herds are prevented. Farmers and local authorities must be made aware of the improvements in animal health and, thus, on production that can be gained through the control of these infections. The importance of herd biosecurity must be stressed, and the information necessary to achieve a sufficient level of biosecurity must be provided. This is especially important in the context of a future intensification of the dairy production. We conclude, based on our results, that the BVDV and BHV-1 situation in the region is favourable

\section{Acknowledgement}

The authors thank Dr. Suvichai Rojanasthein and his colleagues for bulk tank milk and data collection from dairy herds in the Chiangmai province. We are also grateful to the staff of the Dairy Farming Promotion Organisation for collection of bulk tank milk 
from milk centres 3-7. Jaruwan Kampa is a holder of a scholarship from the Swedish Foundation for International Cooperation in Research and Higher Education (STINT).

\section{References}

Ackermann M, Peterhans E, Wyler R: DNA of bovine herpesvirus type 1 in the trigeminal ganglia of latently infected calves. Am. J. Vet. Res. 1982, 43 (1), 36-40.

Ackermann M, Müller HK, Bruckner L, Kihm U: Eradication of infectious bovine rhinotracheitis in Switzerland: review and prospects. Vet. Microbiol. 1990, 23 (1-4), 365-370.

Barkema HW, Bartels CJ, van Wuijckhuise L, Hesselink $J W$, Holzhauer $M$, Weber MF, Franken $P$, Kock PA, Bruschke C J, Zimmer GM: Outbreak of bovine virus diarrhea on Dutch dairy farms induced by a bovine herpesvirus 1 marker vaccine contaminated with bovine virus diarrhea virus type 2. [Uitbraak Van Bovine Virus Diarree Op Nederlandse Rundveebedrijven $\mathrm{Na}$ Vaccinatie Met Een Met BVDV Type 2 Gecontamineerd BHV1 Markervaccin.] (In Dutch). Tijdschr. Diergeneeskd. 2001, 126 (6), 158-165

Baule C, van Vuuren M, Lowings J P, Belák S: Genetic heterogeneity of bovine viral diarrhoea viruses isolated in Southern Africa. Virus. Res. 1997, 52 (2), 205-220.

Bitsch V, Hansen KE, Rønsholt L: Experiences from the Danish programme for eradication of bovine virus diarrhoea (BVD) 1994-1998 with special reference to legislation and causes of infection. Vet. Microbiol. 2000, 77 (1-2), 137-143.

Bitsch V, Ronshølt L: Control of bovine viral diarrhea virus infection without vaccines. Vet. Clin. North. Am. Food. Anim. Pract. 1995, 11 (3), 627 640 .

Brock $K V$ : Strategies for the control and prevention of bovine viral diarrhea virus. Vet. Clin. North. Am. Food. Anim. Pract. 2004, 20, 171-180.

Coria $M F$, McClurkin $A W$ : Specific immune tolerance in an apparently healthy bull persistently infected with bovine viral diarrhea virus. J. Am. Vet. Med. Ass. 1978, 172 (4), 449-451

Department of Livestock Development: Statistics of dairy cattle on 1st Jaunary 2002. Satistics branch, Planning division, Department of Livestock Development, Thailand.

Fredriksen B, Sandvik T, Løken T, Ødegaard SA: Level and duration of serum antibodies in cattle infected experimentally and naturally with bo- vine virus diarrhoea virus. Vet. Rec. 1999, 144 (5), 111-114.

Gibbs EPJ, Rweyemam MM: Bovine herpesvirus 1. Vet. Bull. 1977, 47, 317-343.

Graham D A, German A, McLaren IE, Fitzpatrick $D A$ : Testing of bulk tank milk from Northern Ireland dairy herds for viral RNA and antibody to bovine viral diarrhoea virus. Vet. Rec. 2001, 149 (9), 261-265.

Houe H: Epidemiology of bovine viral diarrhea virus. Vet. Clin. North. Am. Food. Anim. Pract. 1995, 11 (3), 521-547.

Houe $H$ : Epidemiological features and economical importance of bovine virus diarrhoea virus (BVDV) infections. Vet. Microbiol. 1999, 64 (23), 89-107.

Juntti N, Larsson B, Fossum C: The use of monoclonal antibodies in enzyme linked immunosorbent assays for detection of antibodies to bovine viral diarrhoea virus. Zentralbl. Veterinarmed B. 1987, 34 (5), 356-363.

Kaashoek MJ, Rijsewijk F A, van Oirschot J T: Persistence of antibodies against bovine herpesvirus 1 and virus reactivation two to three years after infection. Vet. Microbiol. 1996, 53 (1-2), 103110.

Kahrs RF: 2001. Infectious bovine rhinotracheitis; In: Viral diseases of cattle. 2nd ed., Iowa state university. pp. 159-170.

Lindberg $A L$ : Bovine viral diarrhoea virus infections and its control. A review. Vet. Q. 2003, 25 (1), 116.

Lindberg AL, Alenius $S$ : Principles for eradication of bovine viral diarrhoea virus (BVDV) infections in cattle populations. Vet. Microbiol. 1999, 64 (23), 197-222.

Mainar-Jaime RC, Berzal-Herranz B, Arias P, RojoVázquez FA: Epidemiological pattern and risk factors associated with bovine viral-diarrhoea virus (BVDV) infection in a non-vaccinated dairy-cattle population from the Asturias region of Spain. Prev. Vet. Med. 2001, 52 (1), 63-73.

Nettleton PF, Entrican G: Ruminant pestiviruses. Br. Vet. J. 1995, 151 (6), 615-642.

Niskanen R, Alenius S, Larsson B, Jacobsson SO: Determination of level of antibodies to bovine virus diarrhoea virus (BVDV) in bulk tank milk as a tool in the diagnosis and prophylaxis of BVDV infections in dairy herds. Arch. Virol. Suppl. 1991, 3, 245-251.

Nuotio L, Juvonen M, Neuvonen E, Sihvonen L, Husu-Kallio J: Prevalence and geographic distri- 
bution of bovine viral diarrhoea (BVD) infection in Finland 1993-1997. Vet. Microbiol. 1999, 64 (2-3), 231-235.

Obando RC, Hidalgo M, Merza M, Montoya A, Klingeborn B, Moreno-López J: Seroprevalence to bovine virus diarrhoea virus and other viruses of the bovine respiratory complex in Venezuela (Apure State). Prev. Vet. Med. 1999, 41 (4), 271 278.

O'Rourke K: BVDV: 40 years of effort and the disease still has a firm hold. J. Am. Vet. Med. Ass. 2002, 220 (12), 1770-1773.

Paton D J, Christiansen KH, Alenius S, Cranwell MP, Pritchard GC, Drew TW: Prevalence of antibodies to bovine virus diarrhoea virus and other viruses in bulk tank milk in England and Wales. Vet. Rec. 1998, 142 (15), 385-391.

Pritchard GC: Epidemiology of BHV-1 infection in cattle breeding herds in Norfolk. In Thrusfield, M.V., (Ed.) Proceedings of the Society for Veterinary Epidemiology and Preventive Medicine, Edinburgh, April 1-3, 1992, 169-185.

Rweyeтати MM, Fernandez AA, Espinosa AM, Schudel AA, Lager IA, Mueller SB: Incidence, epidemiology and control of bovine virus diarrhoea virus in South America. Rev. Sci. Tech. 1990, 9 (1), 207-221.

SCAHAW (Scientific Committee on Animal Health and Animal Welfare): Report on Bovine Herpesvirus 1 (BHV1) marker vaccines and the accompanying tests. European Commission, Sanco/C3/AH/R20/2000, October, 25th 2000, p. 2.

Ståhl K, Rivera H, Vågsholm I, Moreno-López J: Bulk milk testing for antibody seroprevalences to BVDV and BHV-1 in a rural region of Peru. Prev. Vet. Med. 2002, 56 (3), 193-202.

Straub OC: Advances in BHV1 (IBR) research. Dtsch. Tierarztl. Wochenschr. 2001, 108 (10), 419-422.

Synge BA, Clark AM, Moar JA, Nicolson JT, Nettleton PF, Herring JA: The control of bovine virus diarrhoea virus in Shetland. Vet. Microbiol. 1999, 64 (2-3), 223-229.

Valle PS, Martin SW, Tremblay R, Bateman K: Factors associated with being a bovine-virus diarrhoea (BVD) seropositive dairy herd in the More and Romsdal County of Norway. Prev. Vet. Med. 1999, 40 (3-4), 165-177.

van Oirschot JT, Kaashoek MJ, Rijsewijk FA: Advances in the development and evaluation of bovine herpesvirus 1 vaccines. Vet. Microbiol. 1996, 53 (1-2), 43-54.
Viltrop A, Alaots J, Pärn M, Must K: Natural changes in the spread of bovine viral diarrhoea virus (BVDV) among Estonian cattle. J. Vet. Med. B. Infect. Dis. Vet. Public Health. 2002, 49 (6), 263269.

Virakul P, Suadsong S, Suwimonteerabutr J, Singlor $J$ : Prevalence of infectious bobine rhinotracheitis (IBR), bovine viral diarrea (BVD), parainfluenza-3 (PI-3) and bovine respiratory syncytial (BRS) viruses in Thai dairy farms. Thai. J. Vet. Med. 1997, 27, 295-313.

Waage S, Krogsrud J, Nyberg O: The Norwegian programme for eradication of bovine viral diarrhoea/mucosal desease. In18th. World Buitatrics Congress: 26th Congress of the Italian Association of Buiatrics, Augusti 29-September 2, 1994, Bologna, Italy.pp.773-775.

\section{Sammanfattning}

$B V D V$ och BHV-1 infektioner i mjölkkobesättningar $i$ norra och nordöstra Thailand.

Tankmjölksprover insamlades från 220 mjölkkobesättningar belägna i 2 regioner i norra respektive nordöstra Thailand. Insamlingen gjordes vid 9 regionala mjölkinsamlingscentra. Ett urval bestående av 11 besättningar gjordes för individuell provtagning. Samtliga prover analyserades medelst indirekt ELISA avseende förekomst av antikroppar mot BVDV och BHV-1. Resultaten visade en måttlig exponeringsgrad av såväl BVDV som BHV-1 (73\% respektive 67\%). Den låga förekomsten av besättningar med höga nivåer BVDV-antikroppar i tankmjölk $(13 \%)$ och den låga individuella BVDV- respektive BHV-1-seroprevalensen bland ungdjur talar dock för en låg grad av reaktivering av latent BHV-1 och en låg prevalens av aktiv BVDV-infektion. Resultaten från den individuella provtagningen indikerar en progressiv självsanerande process i 9 av de 11 besättningarna.

Vi fann dessutom en förvånansvärt låg prevalens av såväl BVDV som BHV-1 bland de besättningar som tillhörde uppsamlingsområdet för ett av de nio mjölkinsamlingscentra. Dessa besättningar etablerades 510 år tidigare än majoriteten av de övriga besättningarna. Vi tror att den nyrekrytering som skett under årens lopp i dessa besättningar inneburit att importerade infekterade djur ersatts, och att detta resulterat $\mathrm{i}$ en nästintill total självsanering av BVDV och BHV1. 
Sammanfattningsvis konstaterade vi att den regionala situationen avseende BVDV och BHV-1 var god. Vi fann indikationer på en självsanerande process i besättningarna och vi är övertygade om att denna kommer att fortsätta så länge som man är medveten om vikten av en god biosäkerhet. Detta kommer att bli särskilt viktigt vid en framtida intensifiering av mjölkproduktionen i regionen.

\section{(Received March 5, 2004; accepted August 25, 2004).}

Reprints may be obtained from: K. Ståhl, Division of Parasitology and Virology, Department of Biomedical Sciences and Veterinary Public Health, Faculty of Veterinary Medicine and Animal Sciences, Swedish University of Agricultural Sciences, Box 7036, SE-75007 Uppsala, Sweden. E-mail: Karl.Stahl@bvf.slu.se, tel: +46 1867 46 28, fax: +46 18674669 . 